\title{
TOWARD AN EQUITABLE AND WORKABLE PROGRAM OF MOBILE HOME TAXATION
}

\section{INTRODUCTION}

INCREASED use of mobile homes as permanent housing invites re-examination and reappraisal of mobile home taxation. This Note will evaluate existing tax practices in light of the functions mobile homes presently perform, and suggest a tax system calculated to promote equality of tax treatment between owners of mobile homes and owners of conventional housing.

Between 1951 and 1956 the mobile home population doubled $;^{1}$ it currently totals over $3,000,000$ persons. ${ }^{2}$ The number of mobile homes in use grew from 550,000 in $1953^{3}$ to $1,200,000$ in 1959.4 This figure has been augmented by mobile homes recently produced-produced at a rate which exceeds 10 per cent of the private single family housing starts in this country.

For many years communities viewed the house trailer as the source of at least three major problems: its presence was expected to blight surrounding areas, causing property values to fall; its occupants were often viewed as personally undesirable; and the municipal expense attributable to trailerites was expected to exceed the revenue which could be raised from them.

Community fear of blight can be traced to the low quality of both the early trailers and their parking facilities. Economic conditions of the 'thirties, followed by wartime housing shortages and rapid relocations of the labor force, pressed many thousands of unattractive trailers into permanent use. ${ }^{0}$ Often these units were without running water or sanitary facilities. ${ }^{7}$ There

1. Hodes \& Robertson, The Law of Mobile Hodes 3 (1957) [hereinafter cited Hodes \& ROBERTSON].

2. Bartley \& Batr, Mobile Hone Parks and Comprehensive Community Planning 12 (1960) [hereinafter cited BARTLEY \& BAIR].

3. 57 Dick. L. Rev. 338 (1953).

4. Fogarty, Trailer Parks: The Wheeled Suburbs, 111 Architectural Forum, July 1959, p. 127 [hereinafter cited as Fogarty].

5. Batr, Mobile Homes and the Generai Housing Supply, Nov. 28, 1961, p. 2.

For statistical purposes units over 29 feet in length have been considered mobile homes. Statistical Abstract of the Untred States 760 (1961) ; Construction Review, March 1961, p. 4. Most "travel trailers" are 15-16 feet long. Few units between 25 and 40 feet in length are sold. Peter Henry Associates, The Market for Light Trailer Brakes in the U.S.A., 1960, p. 23.

6. Some people, forced from their homes by mortgage foreclosure, took refuge in trailers. See Fogarty 127; Cady v. City of Detroit, 289 Mich. 499, 504, 286 N.W. 805, (1939). The federal government alone purchased 38,00022 -foot trailers to house production workers during World War II. Hodes \& RoBersson 2. For contemporary discussion of efforts made, by particular communities, to meet problems created by the infux of trailer housed defense workers, see Franklin, On the Local Front, 31 NaT'L MunIc. REv. 336-38 (1942).

7. Hodes \& Robertson 1; see Renker v. Village of Brooklyn, 139 Ohio St. 484, 488, 40 N.E.2d 925, 927 (1942): Wellington, Trailer Camp Slums, 87 The Survey 418, 419 (1951). 
were no construction standards to insure even minimum protection against fire or collapse. ${ }^{8}$ They were parked in areas which were usually crowded, poorly equipped, and generally unsuited to residential use. As a result, conditions in these parks seldom exceeded minimum health and sanitation standards. ${ }^{\circ}$ The specter of such parks teeming with tiny trailers made community apprehension understandable. But substantial improvements in the quality of both mobile homes and park facilities may have undermined the bases for this antipathy today. The mobile home currently produced is an attractive, completely furnished, efficiently spacious dwelling for which national construction standards have been adopted and enforced by the manufacturers' associations. ${ }^{10}$ Some of today's parks are landscaped, and feature ample lots imaginatively arranged around paved streets. ${ }^{11}$ Recreation facilities-such as swimming pools, boat docks and playgrounds-found in high quality parks could be the envy of conventional housing developments. Although many parks have yet to match such progress, ${ }^{12}$ communities have ample power to require improvement of existing facilities and to set high standards for future park construction. ${ }^{13}$ They need only exercise it.

Community distaste for trailer dwellers personally developed at a time when the trailerites were often considered footloose, nomadic people unlikely to make any positive contribution to community life. ${ }^{14}$ The early trailer was

8. Many early trailers were homemade. A Fortune Magazine survey found that only 35,000 of the 55,000 trailers produced in 1936 were factory made. Cited in Preface to Asierican Municipal Association, The House Trailer (Report 115, 1937) [hereinafter cited as 1937 REPORT]. The possibility of conflagration in areas congested with flammable trailers was recognized, $i d$. at 1 , and communities sought to reduce this potential hazard by prohibiting trailers, Ayrerican Municipal Association, House Trailer Regulation (Report 147, July 1941, at 9-10) [hereinafter cited as 1941 REPORT], or requiring park owners to take such precautions as providing fire fighting equipment, id. at 7-9.

9. See generally BARTLEY \& BaIR 1-3; Wellington, Trailer Camp Slums, 87 The SuRveY 418 (1951) ; Fogarty 128.

10. Mobile Home Manufacturers Association, 10th Annual Industry Report 8 (1961) [hereinafter cited 10TE ANNUAL REPORT]. These standards, however, apply only to electrical, plumbing, and heating equipment and installations; they apparently do not cover exterior construction. BARTLEY \& BAIR 31.

11. Fogarty 128.

12. 10TH ANNUAL REPORT 12; Fogarty bluntly summarized the situation:

Indeed, if the standards of the average trailer were even remotely approached by those of the average trailer park, there might be considerable community tolerance of trailer living, which there is not. The rub is in the trailer park.

Fogarty 128.

13. See Bartley \& Bair 101-05.

14. Some of the best examples of this conception of trailer residents are found in judicial opinions. See, e.g., Commissioners of Anne Arundel County v. English, $182 \mathrm{Md}$. 514,530 (1943) ("Other forms of taxation to reach the nomadic type of people who reside in such structures have been suggested.") ; Cady v. City of Detroit, 289 Mich. 499, 506, 514, 286 N.W. 805, 810-11 (1939) (Court upheld ordinance limiting trailer residence stating, "Ordinances having for their purpose ... the attraction of a desirable citizenship . . . are within the proper ambit of the police power.") ; Streyle v. Board of Assessors, 173 
used primarily by tourists and transient workers $;$;5 the permanent residents who did use trailers were likely to be low income workers with temporary positions. ${ }^{16}$ Mobile homes, however, can no longer be said to be inhabited primarily by migratory paupers; according to recent surveys, the present occupations and incomes of their occupants vary widely. Skilled workers, many of whom are engaged in construction or mineral development, now seem to form the largest single group of mobile home owners. ${ }^{17}$ Many mobile homes are also used by military personnel, ${ }^{18}$ young couples, ${ }^{19}$ and retired persons. ${ }^{20}$ Even professional people, perhaps attracted by the comfort available in a high quality mobile home and park, perhaps by tax economies, ${ }^{21}$ currently represent a large segment of the mobile home population. ${ }^{22}$ With the increasing variety of occupational groups living in mobile homes has come a substantial upgrading in income level. In 1958, the median income of mobile home dwellers $(\$ 5,250)^{23}$ was approximately the same as the national average $(\$ 5,300){ }^{24}$ There seems little justification, therefore, for any continuing personal antipathy toward mobile home dwellers as a group.

If developments in home and park construction should have alleviated community fears that mobile homes cause blight and attract undesirable residents, increased use of mobile homes has aggravated the financial problems of

Pa. Super. 324, 327 (1953) ("Trailer folk for the most part are nomads at heart . ..."); Crawford v. Wesleyville, 68 Pa. D. \& C. 215, 218 (C.P. 1949) (Parks “. . . frequently attract a nomadic, promiscuous and careless population ...."); Yorkville v. Fonk, 3 Wis.2d 371, 376-77, 88 N.W.2d 319, 322, appeal dismissed, 358 U.S. 58 (1958) ("Trailers . . lack the permanency ... conducive to the well-ordered development of the community.").

15. In 1937 "the vast majority of trailerites" were tourists whose average residence varied from one to thirty days. Few trailers were then used by transient workers. 1937 REPORT 4. The use by workers, foreseen in 1937, materialized during World War II. See generally Franklin, On the Local Front 31 NAT'L Munrc. Rev. 336 (1942); Fogarty 127.

16. See 1937 Report 20; Fogarty 127; Wellington, Trailer Camts Slumss, 87 SuRvey 418,421 (1951).

17. Thirty seven per cent of mobile home owners are skilled workers. 197 EcoNomrst $1233(1960)$.

18. Military personnel own $20 \%$ of the mobile homes. Ibid.

19. Cf. HODES \& ROBERTSON 4-5.

20. Approximately $10 \%$ of mobile homes are owned by retired people. 197 Econosist 1233 (1960).

21. See BartLey \& Batr 110.

22. Professional people own $18 \%$ of the mobile homes. 197 Economist 1233 (1960).

23. BARTLEY \& BATR 8.

24. U.S. Dep't of Cominerce, Current Population Reports, Series P-60, No. 22, Jan. 15,1960 , at 1 .

The proportion of mobile home owners with annual incomes above $\$ 2,000$, from $\$ 2,000$ to $\$ 5,000$, and from $\$ 5,000$ to $\$ 7,000$ is greater than that of the general population. In $1958,14.3 \%$ of United States families had incomes of $\$ 2,000$ or less, but only $3.2 \%$ of mobile home families did. A greater proportion of mobile home families had incomes between $\$ 2,000$ and $\$ 5,000: 41.8 \%$ to $34.4 \%$. In the $\$ 5,000-\$ 7,000$ bracket were $31.3 \%$ of mobile home families, but only $24.4 \%$ of other families. Over $\$ 7,000$ there was only a slight gap: $23.7 \%$ of mobile home families, $26.9 \%$ of all other families. Compare BARTLEY \& BAIR 8, with U.S. DEP'T of Commerce, Current Population Reports, Series P-60, No. 33, Jan. 15, 1960, at 1. 
many municipalities. ${ }^{25}$ Tax programs designed to cope with transients' use of early trailers may not be adequate where mobile homes are used as permanent dwellings. The mobility of the early "trailers" and the transiency of their occupants made impractical a tax which required continuous local discovery, assessment and enforcement. ${ }^{26}$ In view of these collection difficulties, the drain on community budgets caused by the relatively few, usually low-income trailerites may not have warranted the development of a particular tax program for them. In any event, when trailer dwellers were viewed as a significant financial liability, the problem was often eliminated rather than solved by prohibiting trailers or limiting the time a trailer might remain in the community. ${ }^{27}$ This ostrich approach is no longer adequate or necessary. Periods of mobile home residence have gradually increased and it has been claimed that mobile home residents are now as permanent as residents of multifamily conventional housing. ${ }^{28}$ This increasing immobility, by relieving the pressure for speedy collection, should permit consideration of a wider range of tax alternatives. Since mobile homes today require "the entire range of urban facilities," 29 it is worth discovering how their occupants can best be made to pay "their fair share" of community expenses.

\section{Analysis of Alternative Tax Programs}

Mobile homes have usually been taxed, if at all, as motor vehicles, as personal property or through periodic fees. Occasionally, local assessors have attempted to tax mobile homes as realty, ${ }^{30}$ and several states have recently enacted statutes authorizing the inclusion of mobile homes in realty assessments. ${ }^{31}$ In evaluating the several forms of mobile home taxation, it will be assumed that communities which permit the use of mobile homes as residences will expect their occupants to support local budgets and that these mobile

25. Municipal expenditures attributable to mobile home residents are similar to those occasioned by other residents. Expense is incurred inspecting and regulating parks, furnishing fire and police protection, and disposing of sewage and garbage. Pressure placed on school facilities and budgets by children from mobile home families has been a constant problem for communities. See 1937 Report 20; 1941 Report 24-25; BARTLEY \& Bair 107.

26. See 1937 Report 18-19.

27. See, e.g., 1941 Report 18; Brooklyn, Ohio, Ordinance to Regulate Trailers and Trailer Camps, July 8, 1940 (construed and upheld in Renker v. City of Brooklyn, 139 Ohio St. 484, 40 N.E.2d 925 (1942) and Stary v. City of Brooklyn, 162 Ohio St. 120, 121 N.E.2d 11 (1954) ; Spitler v. Town of Munster, 214 Ind. 75, 14 N.E.2d 579 (1938) (ordinance limiting mobile home residence to 30 days upheld).

28. BARTLEY \& BAIR 6. In 1954 the average mobile home was moved about once each year, Comment, 22 U. CHI. L. REv. 738, 751 n.66 (1955); today the figure is 24 to 30 months. Business Week, March 19, 1960, p. 62.

29. 10th AnNual Report 7.

30. See, c.g., Stewart v. Carrington, 203 Misc. 543, 119 N.Y.S.2d 7.78 (Sup. Ct. 1953); Mason Appeal, 75 Pa. D. \& C. 1 (C.P. 1950).

31. See N.Y. Tax Laws $\$ 2$ (6-a); PA. Stat. Ann. tit. 72, § 5020-021 (Supp. 1960); Mont. Rev. Codes Ann. \$ \$4-301 (Supp. 1961). 
home owners should be taxed on the same basis as other residents unless adequate reasons can be found for disparate treatment.

\section{Motor Vehicle Tax}

When the homes were highly mobile, the ease of collecting a motor vehicle tax may have justified its use in preference to other means of taxation. Enforcement could be facilitated by requiring mobile homes to bear license plates when in transit and authorizing police to halt units moving without a license. ${ }^{32}$ This ease of collection perhaps offset the fact that in many states the payment of a motor vehicle tax exempted the mobile home from local taxation. ${ }^{33}$ On the other hand, under the early programs state-collected motor vehicle tax proceeds were not returned to the locality in which the mobile home was located. ${ }^{34}$ Thus, the communities which supplied services to the trailerites received no compensation from the vehicle tax. Furthermore, differences in the value of individual units were reflected, if at all, ${ }^{35}$ only crudely in registration fees graduated according to weight, ${ }^{36}$ length ${ }^{37}$ or number of supporting axles. ${ }^{38}$

Perhaps partially in recognition of the developments in the mobile home field, numerous modifications have been made in the administration of vehicle tax systems. Today's motor vehicle tax receipts from mobile homes are usually distributed to the local governments in which the homes are located.90 Current valuation techniques have been substantially refined also, with most states graduating registration fees by manufacturer's list price or actual resale value of similar models. ${ }^{40}$ Even now, however, state valuation based solely on manufacturer's price seldom acknowledges the state policy on taxing home furnishings: in states where furnishings are taxed, those added to a mobile home after purchase are not, while in states where furnishings are not otherwise taxed, those included in the manufacturer's price may be. ${ }^{41}$

32. See, e.g., ArIz. Rev. Srat. ANN. § 28-302 (1956). In Oregon, sheriffs are supposed to search for unlicensed mobile homes even if not in transit. ORE. REv. Stat. § 481.504 (1959).

33. E.g., Ariz. Rev. Stat. Ann. § 42-644 (1956); Cal. Rev. \& Tax Code § 10758; Fla. Stat. \$ 320.081 (1958) ; N.M. Stat. Ann. \$ 64-11-14 (1960).

34. 1937 Report 20-21; cf. Fla. Stat. Ann. $\$ 320.20$ (1958).

35. E.g., Fla. Stat. Ann. § 320.081 (1958) ; Dec. Code Ann. tit. 14, § 1931 (Supp. 1960).

36. E.g., Conn. Gen. Stat. Rev. § 14-47 (1958); Me. Rev. Stat. Ann. ch. 22, § 16-III (1954) ; Mich. Stat. ANN. \$ 9.2501 (b) (1960).

37. E.g., Idaho Sess. Laws 1953, ch. 64, \& 1, at 256 .

38. N.M. Stat. ANN. \& 64-11-1.2(B) (1960).

39. E.g., Artz. Rev. Stat. Ann. § 28-1591 (B) (1956); Cal. Rev. \& Tax Code § 11003.3. Some states still retain a portion of the registration receipts. E.g., IDAHO CODE ANN. \$ 49-155 (1961) ; N.M. Stat. Ann. § 64-11-12 (1960).

40. E.g., ArIz. Const. art. 9, § 11; Cat. Rev. \& TAx Code § 10752; Colo. Rev. Stat.

ANN. § 13-4-6 (1953); ME. REv. ANN. ch. 22, § 51-A (1954).

41. Some states, however, do reduce mobile home valuations specifically to represent the value of furnishings. E.g., CoLo. REv. Stat. ANN. \& 13-5-6 (1953). 
Fundamentally, however, the motor vehicle tax is an inappropriate means of taxing today's relatively permanent mobile homes. Only with difficultyif at all-could centrally determined valuation schemes be modified to take account of the often substantial permanent additions to mobile homes. ${ }^{42}$ But even if this could be accomplished, the vehicle tax would remain an unnecessarily inaccurate means of compensating communities for the governmental cost occasioned by mobile homes and their occupants, for vehicle taxes do not reflect differences in the level of public services provided by the various communities within a state. ${ }^{43}$ While the cost of municipal services is generally mirrored in local real and personal property assessment ratios and mill rates, motor vehicle taxes are generally uniform throughout a state despite the differing expenditure levels of its municipalities. The inevitable result is relative under-taxation of mobile homes in some areas and relative over-taxation in others. ${ }^{4}$

\section{Personal Property Tax}

In many states mobile homes are taxed as personal property. ${ }^{45}$ In some of these, mobile homes on which vehicle taxes have been paid are exempted from the personal property levy. ${ }^{46}$ In the others, the mobile home is treated essentially like other property in the community. Usually both the assessment of the home and the determination of the mill rate are governed by local practices. ${ }^{47}$ The personal property tax is therefore inherently better suited to reflecting the general level of local services than is any uniform state-wide schedule of license fees.

The personal property tax, however, is not a completely satisfactory solution to the problem of mobile home taxation. Many states do not presently tax personal property at all. ${ }^{48}$ In such states it would be inefficient to administer a special tax on this one form of property. And even where a personal property tax exists, rarely is it effectively collected. ${ }^{49}$ There are potential en-

42. Additions may be as large as the mobile home itself Bair, Mobile Homes and the General Housing Supply, Nov. 28, 1961, p. 1.

43. Cf. Iowa Legislative Research Bureau, Taxation of Mobile Homes, Bulletin 21, p. 10 (1959) [hereinafter cited Iowa Bulletin].

44. This problem is not eliminated by applying an average state tax rate to the centrally determined value as is done in several states. See, e.g., ArIz. Const. art. $9, \S 11$; Neb. Rev. Stat. \& 77.1240.01 (1958).

45. E.g., Ariz. Rev. Stat. Ann. § 42-643 (1956); Fla. Stat. ANn. § 200.45 (1958); Ill. ANn. STAT. ch. 120, § 499 (Smith-Hurd 1954); KAN. GEN. STAT. AnN. § 79-101 (1949).

46. See, e.g., Ariz. Rev. Stat. Ann. § $42-644$ (1956); Fla. Stat. Ann. § 320.081 (1958).

47. But see Ohro Rev. Code ANn. § 4503.06(E) (Page Supp. 1961). The new Ohio mobile home tax is computed and assessed locally, using the local tax rate, but the value of the home is determined by a statutory formula.

48. E.g., Del. Code AnN. tit. 30, § 102 (1953); N.Y. TAX Laws § 3; cf. Ohto Rev. Code ANN. § 5709.01 (1954).

49. Bartley \& BaIr 111-12; Morton, Housing Taxation 77 (1955); see generally 
forcement procedures: Some personal property tax statutes permit distraint, attachment, or garnishment even before taxes are due. ${ }^{50}$ Before such severe sanctions are applied to mobile homes, however, cognizance ought to be taken of the uniform reluctance to invoke them against other forms of housing. Statutes which permit forced sales of real estate for delinquent taxes invariably provide substantial redemption periods; a sale of personal property for taxes, on the other hand, is almost always absolute-giving the owner no opportunity to redeem. ${ }^{51}$ It is difficult to justify disregard for the principle that a home should not be lost because its owner is temporarily unable to pay taxes on the ground that the home is mobile and therefore "personal," not "real" property. Similarly, it is difficult to see why mobile home owners who would be entitled to special exemptions as veterans ${ }^{52}$ or widows, ${ }^{63}$ for example, if their homes had been classified as realty, should be denied similar exemptions simply because their homes are taxed as personalty.

\section{The Fee System}

Some states and communities have sought to charge mobile home dwellers for the public benefits they enjoy by collecting a periodic fee from the owners of the homes or parks. This fee system seems to have several advantages for the local government which the motor vehicle and personal property taxes often lack. The proceeds go directly to local governments or school districts in which the mobile homes are located. ${ }^{54}$ The difficulties of appraising individual units are usually avoided by imposing uniform fees-ranging from $\$ 15$ to $\$ 120$ per year-regardless of the value of the home. ${ }^{65}$ When park owners are held responsible for the fee collection, as is often the case, the local government is saved the expense of locating homes and collecting fees..$^{50}$ Moreover, when the park owner's fee takes the form of a license tax grad-

Poole, Public Finance \& Econousic Welfare 279 (1956) ; Due, Government Finance 391 (1959).

50. E.g., Ala. Code tit. 37, § 694 (1959); Artz. Rev. Stat. Ann. $\$ 42-349$ (1956); ARK. STAt. § 84-914 (1960).

51. E.g., compare Ariz. Rev. Stat. Ann. \$42-421(A) (1956), with Ariz. Rev. Stat. ANN. \$ 42-614 (C) (1956). Mobile homes in California are protected from sale for taxes. Cal. Crv. Proc. Code $\$ \$ 690.24, .27$.

52. See, c.g., Mass. Ann. Laws ch. 59, § 5 (22d exemption) (Supp. 1961).

53. Ibid. (17th exemption).

54. E.g., Del. Code Ann. tit. 14, § 1933 (Supp. 1960).

55. Delaware imposes a flat $\$ 15$ annual fee on each mobile home which has been in the state 30 days or more. Del. Code Ann. tit. 14, 1931 (Supp. 1960). Neptune City, New Jersey attempted to impose a fee of $\$ 10$ per month per home on park operators. This fee was found confiscatory and the enabling ordinance was set aside. Hoffman v. Neptune City, 137 N.J.L. 485 (1948). But cf. Iowa imposes a monthly fee graduated according to the home's length. Iowa Code ANn. § 135D.9 (Supp. 1960).

56. E.g., Iowa Code Ann. § 135D.10 (Supp. 1960); Mrch. Stat. Ann. § $5.278(71)$ (1961) ; Wis. Stat. ANn. § 66.058(3) (c) (Supp. 1961); cf. Kelly v. City of San Diego, 63 Cal. App. 2d 638, 640-41 (1944); Mason Appeal, 75 Pa. D. \& C. 1, 2-3 (C.P. 1950). 
uated according to the capacity of the park, it tends to insure a predictable, collectible, minimum contribution on behalf of (and ultimately from) mobile home dwellers. ${ }^{57}$ And, in states which consider mobile homes to be personal property non-taxable under state law or which permit them to be registered as motor vehicles and exempt from local taxation once registered, the fee system may be the only means available to local governments for collecting revenue, directly or indirectly, from the home owners.

On the other hand, the fee system, like both personal property and motor vehicle taxes, treats mobile home occupants as distinct from other residents. While the realty tax imposed on others is keyed to property value, the fees paid by mobile home inhabitants do not reflect disparities in the values of individual homes and additions. ${ }^{58}$ Indeed, some people advocate a fee system precisely because it need not be tied to property values and can be based on the costs of furnishing municipal services directly to mobile home residents..$^{59}$ This differential treatment has prompted some mobile home owners to challenge fees as a denial of their right to equal protection. ${ }^{60}$ While some courts seem to have so held, the equal protection finding is often make-weight, state law providing sufficient grounds for refusing to enforce the fees. ${ }^{61}$ Elsewhere, moreover, fee systems have been held constitutional when contested on equal protection grounds. ${ }^{2}$ And this result seems more in line with the long-term trend toward a more permissive review of the reasonableness of distinctions drawn by legislatures for tax purposes. ${ }^{63}$

57. E.g., Colo. Rev. Stat. Ann. § 13-14-2 (1954); Irl. Ann. Stat. ch. 111 12/2, § 169 (Smith-Hurd Supp. 1960) ; cf. Kelly v. City of San Diego, 63 Cal. App. 2d 638, 640 (1944); Mfichaels v. Township Comm. of Pemberton, 3 N.J. Super. 523, 527 (1949); White v. City of Richmond, $293 \mathrm{Ky} .477,478$ (1943).

58. Barnes v. City of West Allis, 275 Wis. 31, 35, 81 N.W.2d 75, 78 (1957) (uniform fee imposed on homes valued from $\$ 500$ to $\$ 5,000$ ); Anne Arundel County v. English, 182 Md. 514, 524, 35 A.2d 135, 140 (1943) (uniform fee imposed on homes valued from $\$ 300$ to $\$ 2,500$ ) ; Iowa Bulletin 9-10.

Mobile homes currently produced range in price from $\$ 3,500$ to more than $\$ 12,000$. $10 \mathrm{TH}$ AnNual Report 6.

59. See 1937 Report 19-20; 1941 Report 21-22; Iowa Bulletin 10-11.

60. See Anne Arundel County v. English, 182 Md. 514, 35 A.2d 135 (1943) ; Rapa v. Haines, 101 N.E.2d 733 (Ct. C.P. 1951), aff'd, 113 N.E.2d 121 (County Ct. App.), appeal dismissed, 158 Ohio St. 275, 108 N.E.2d 833 (1952) ; Crawford v. Wesleyville, $68 \mathrm{~Pa}$. D. \& C. 215 (C.P. 1949); Barnes v. City of West Allis, 275 Wis. 31, 81 N.W.2d 75 (1957).

61. Anne Arundel County v. English, stlpra note 60 (fee found a property tax not apportioned according to value, as required by Maryland Declaration of Rights.) Crawford v. Wesleyville, supra note 60, (ordinance imposing a fee violated Pennsylvania Constitution by attempting to license "the right to live in a home....")

62. Barnes v. City of West Allis, 275 Wis. 31, 81 N.W.2d 75 (1957) ; Rapa v. Haines, 101 N.E.2d 733 (Ct. C.P. 1951), aff'd, 113 N.E.2d 121 (County Ct. App.), appeal dismissed, 158 Ohio St. 275, 108 N.E.2d 833 (1952).

63. See, e.g., Allied Stores, Inc. v. Bowers, 358 U.S. 522 (1959); Charleston Fed. Sav. \& Loan Ass'n v. Alderson, 324 U.S. 182 (1945) ; Nashville, C. \& St. L. Ry. v. Browning, 310 U.S. $362(1940)$. 
An attempt to make mobile home residents responsible inter se for the additional expenses attributable to them by adoption of a fee system would involve conceptually difficult accounting problems. For example, what proportion of local administrative expense, or police or fire protection costs are really attributable to mobile home residents? Should the cost of municipal recreation facilities be allocated equally to owners who reside in parks furnishing extensive recreational facilities and those who depend on the public facilities? If this special tax treatment of mobile home residents is justified by their potential mobility, should they be required to contribute to permanent community improvements? Should their contribution be limited to a portion of current depreciation? Difficult as these problems may be, an approximate allocation of costs can doubtless be made. ${ }^{04}$ The fundamental objection to taxing mobile homes through fees based on the value of services received lies not in the conceptual difficulties of allocation but in the special treatment of these residents. So long as other dwellings are taxed by an ad valorem property tax, the fee system is subject to the same criticism made of taxing mobile homes as motor vehicles or personal property: It discriminates between residents.

\section{A General Criticism Justified.}

The principal objection therefore to the vehicle tax, the personal property tax, and the fee system as applied to mobile homes is that, since they coexist with another form of tax-the realty tax, applicable to owners of stationary homes-they inevitably cause an undesirable inequality in the tax burdens of the owners of homes. The point is not that the mobile home owner pays more (or less) than his counterpart in a permanent home, but that he is taxed differently. This insistence on equality of tax treatment is predicated on a belief that the once tenable distinction between the occupants of mobile and stationary housing has outlived its utility. ${ }^{65}$ It further assumes that

64. By statute Wisconsin permits communities to compute monthly fees "equal to actual cost of services furnished by the school district ... and the cost of the municipal services ..." Wrs. Stat. Anrs. § 66.058(3)(c) (1957). The constitutionality of this statute was upheld in Barnes v. City of West Allis, 275 Wis. 31, 81 N.W.2d 75 (1957). Over 200 Wisconsin communities have imposed such fees. BARTLEY \& BaIR 116.

65. The reasonableness of the separate classification of mobile homes may well stand or fall on their actual, not potential, mobility. Few dwellings are absolutely immobile; the question is how immobile must a dwelling be to escape the "mobile" classification? As the mobile home becomes increasingly permanent, see note 28 supra and accompanying text, differentiation on the basis of mobility should, and probably will, lose its vitality. State courts seem to have recognized this. See, e.g., New York Trailer Coach Ass'n v. Steckel, 208 Misc. 308, 144 N.Y.S.2d 82 (Sup. Ct. 1955), rev'd on other gronnds, 3 App. Div. 2d 643, 158 N.Y.S.2d 179 (1956) ; Barnes v. Gorham, 12 Misc. 2d 285, 175 N.Y.S.2d 376 (Sup. Ct. 1957). The Wisconsin legislature recently amended its fee statute and no longer applies a monthly fee to a home if the value of additions "equals or exceeds 50 per cent of ... [its] value ..." Wis. Stat. ANN. $\$ 66.058$ (1) (e) (Supp. 1961) (emphasis added). 
equality of tax treatment would focus the community decision process on important policy considerations often obscured by the maintenance of a separate tax program for mobile homes.

Tax equality would eliminate one justification for dissatisfaction with the tax system (even if dissatisfaction itself were not eradicated): residents of standard homes could no longer accuse mobile home owners of failing to pay their "fair share" of community expenses; nor could the mobile home owners any longer object to the discrimination often reflected in fee systems. Such equality might also further the identification of mobile home owners with the community and its acceptance of them. ${ }^{66}$ Those mobile home owners who would find their tax burdens increased by extension of the real property tax might find some other effects to their benefit. Communities which presently prohibit or limit the use of mobile homes might reconsider their position once satisfied that these homes will not be a financial liability. ${ }^{67}$ The mobile home owner might gain a voice in local freeholder elections, where today he is denied a vote even though his home may be more valuable, his tax payments greater, and his residence longer than freeholders. ${ }^{68}$

Elimination of a separate tax scheme for mobile, as distinguished from "permanent," home owners would also increase the effectiveness of legislative policies embraced in exemption statutes. Such policies could, of course, be implemented by being incorporated into more than one tax program (e.g., one for "permanent" property and another for "mobile" homes). Too frequently, however, communities have yielded to the tendency to ignore the internal diversity of the group covered by the special tax or fee system. The result is that sub-groups such as widows, orphans, elderly persons, and veterans who own mobile homes are grouped as mobile home owners and denied exemptions they would receive if only they occupied regular housing units. $^{60}$ This situation ignores the fact that the policies underlying the exemption of the sub-groups apply regardless of whether they live in mobile or stationary housing. If the effect of the exemptions when applied to mobile home owners would be to remove inexpensive mobile homes from the tax rolls and if this is deemed undesirable, the better solution would be to alter the exemption laws, not to withhold the exemption from the widows, orphans, and veterans who live in mobile homes. It is submitted that the dynamics of legislative action are such that this is more likely to be accomplished if all home owners are made subject to the same form of taxation. The question remains, however : what form of tax is to be preferred?

66. See Bartley \& Batr 66.

67. Interview with Sydney Adler, President, Mobilife Corp., Dec. $2,1961$.

68. See State ex rel. Landis v. Gifford, 114 Fla. 872, 154 So. 893 (1934).

69. Compare Mass. ANn. Laws ch. $59, \S 5$ (Supp. 1961) (exempting real property of widows, orphans, aged persons (17th exemption), and disabled veterans (22d A exemption)), with Mass. ANN. Laws ch. 140 § 326 (1957) (imposing monthly fee on mobile home owners without exception). 


\section{Proposed: Extension of Real Property Tax}

The ideal of equal tax treatment could be pursued by extending the realty tax to mobile homes or by taxing stationary homes under a fee system or at the same effective rates applied to mobile homes taxed as personalty. On an abstract level, the choice should perhaps hinge on a prior determination of whether the ad valorem or pay-as-you-go method is more equitable or otherwise socially preferred. That fundamental question, however, may be avoided by one primarily interested in practical alleviation of the present disparity in tax treatment of the owners of mobile as opposed to stationary housing. The laws of legislative inertia clearly indicate that if the unequal tax treatment of a relatively small group is to be corrected and there is a tax which already accounts for the overwhelming proportion of local government revenues, the desired change will be effected-if at all-by an extension of that already predominant tax. The real estate tax accounts for an estimated 85 per cent of local government revenues, 99 per cent of their tax revenues. ${ }^{70}$ As a practical matter, therefore, if mobile home owners are to be accorded tax treatment equal to that of other home owners the modus operandi no doubt will be an extension of the real property tax. ${ }^{71}$

Critical to the likelihood of so extending the realty tax would be its ability to raise at least as much net revenue for the community as presently is received from mobile homes. There would seem to be no reason why mobile home owners as a group should yield less when taxed on an ad valorem basis than when taxed at a flat rate. Some economies of scale in tax collection might even be achieved if, instead of maintaining two tax programs, existing realty $\operatorname{tax}$ machinery were utilized in the taxation of mobile homes. ${ }^{72}$ Even if such economies did not materialize, however, communities which today do not tax mobile homes or tax them ineffectively because they lack an adequate discovery process might find the additional, potential revenue from mobile homes sufficient to make a program worthwhile.

The attempt to apply a realty tax to mobile homes does present some un-

70. U.S. Census Bureau, Summary of Governmental Finances in 1955 at 20 (1956).

71. It should be noted, however, that if the realty tax on mobile homes exceeds the tax currently paid, present mobile home residents may be induced to move their homes to areas where taxes are lower. Mobile home owners are perhaps more likely to move as a result of $\operatorname{tax}$ increases than are owners of conventional housing. Other owners, who would have to sell their homes in order to move to a lower tax area, may find that the market price of their homes has fallen by the capitalized value of the tax. See generally Groves, Finsarcing Government 127-29 (4th ed. 1954). If this has happened, they may remain, reasoning that the effect of the tax increase cannot be avoided by moving.

This being true, the realty tax, with exemptions for favored groups, might be used to "tax out" unwanted mobile home residents. But selective exclusion of low income groups or large families may better be accomplished by setting minimum per capita living space requirements, or raising park standards.

72. See generally Hansen \& Perloff, State \& Local Finance in the National Econosy 74 (1944). 
usual administrative problems at each stage in the taxing process-discovery, assessment, collection, and enforcement. The threshold problem is that of finding the mobile homes, particularly the recent arrivals. This problem is not new to communities which presently tax mobile homes by fee systems or personal property tax; nor is it unique, for communities already facing the similar task of locating regular building additions and new construction. This problem could be solved by making periodic inspections to determine if mobile homes have arrived. Such inspections could be relied on either as the sole method of discovery or as a check on other sources of information. The inspections could be made by the same assessors who presently search for other recent improvements. They would be simplified by the zoning regulations already common in urban areas restricting mobile homes to licensed parks. ${ }^{73}$ Particularly in larger communities, however, the discovery process would be more economical if a permit were required before a mobile home could be located or occupied in the community. ${ }^{74}$ Such a requirement would assist local discovery just as building permit ordinances do in the case of other improvements. A further check would be provided by requiring mobile home owners to declare their destinations when applying for a permit to move their homes; such permits are already required in many states. The issuing agency could then notify the tax assessor of the prospective home. ${ }^{75}$ The efficacy of the moving permit as a discovery device would depend on the ability and willingness of home owners to declare their exact destination, including their intended street address in a metropolitan area, and the good will and efficiency of the issuing agency. As yet another check, park owners could be compelled to report arrivals of mobile homes without permits, or all arrivals in jurisdictions which do not require moving or location permits. ${ }^{78}$

As with any ad valorem tax, the problem of valuation would have to be met if the realty tax were extended to mobile homes. But the availability of manufacturers' original prices and current market values should ease the assessment problem considerably, ${ }^{77}$ and additions to mobile homes should be no more difficult to assess than other building improvements. Some unusual timing problems might arise by virtue of the mobility of the homes, but in view of the relatively low actual turnover of mobile homes the problem should

73. HODES \& ROBERTSON 36 .

74. Hodes \& RoBertson. 37-39. Michigan requires a permit to occupy a mobile home outside a licensed park. Mrch. Stat. ANn. \$ 5.278(21) (1961).

75. Most states require special permits before large mobile homes may be moved. See, e.g., AlA. Code tit. 36, § 91 (1959) ; Ariz. Rev. Stat. Ann. \$§ 28-1002, 1004, 1011 (1956); Ark. Stat. Anw. \& 75-822 (Supp. 1961).

76. Such reports presently are required in many jurisdictions. E.g., Ariz. Rev. Stat. Ann. § 42-642 (1956) ; Ind. Ann. Stat. \& 64-3303 (Supp. 1960) ; Iowa Code ANn. § 135D.9 (Supp. 1960) ; KY. Rev. Stat. § 132.260 (2) (1960).

77. Many states presently use manufacturers' prices or current market values in appraising mobile homes for tax purposes. E.g., Ariz. Const. art. 9, \$ 11 ; CAL. REv. \& TAX Code § 10752; Colo. Rev. Stat. Ann. § 13-5-6(4) (Supp. 1957); Miss. Code Ann. § 10007-10 (Supp. 1958). 
not prove fiscally embarrassing. To be sure, if mobile homes are assessed on one "assessment day" annually, no tax will be received from homes which later enter the taxing district. But if the turnover problem did prove to be serious, it could be met by a continuous or periodic assessment process. ${ }^{78}$ Likewise, where local permits are required before a home may be placed in the community, they might be conditioned upon evidence of payment of the tax for the remainder of the year. Alternatively, continuous taxation of mobile homes might be triggered by notice from moving permits, park owners, or local inspectors. Once the mobile home was located and taxed for the balance of the initial year, it could be treated as other property.

Passing the problem of assessment, it must be decided whether the tax should be levied on the home owner or the land owner. Of course, this question is academic where both home and site have a single owner, as in large subdivided parks in which lots are sold to individuals who place their homes upon them $;^{79}$ in rural areas, where individual mobile homes are placed on their owner's land $;^{80}$ and in parks whose owners rent out the homes as well as the land on which they rest. ${ }^{81}$ In these situations all the property is assessed to the owner of the land; if the mobile home is moved, the land remains as spcurity for the tax. If, on the other hand, a home on a rented site is assessed to the home owner rather than the landowner an important collateral question is whether delinquent taxes could be made to constitute a lien upon the land (though owned by a third party) as well as the home. If the lien is held to apply to the home only, the value of the security is diminished by the ability of the home owner to abscond, taking his home with him. To discourage taxprompted moves, many states presently condition the issuance of moving permits on the exhibition of proper tax receipts. ${ }^{82}$ If so much responsibility for tax enforcement is to rest upon the moving permit, it should be enforced on a state-wide basis. Highway patrols should be instructed to inspect homes in transit for permits stating the date of issue, the destination and the description of the home. Violations should be punished by fines for the home owner and towing agent, or revocation of the towing agent's license. ${ }^{83}$ If only local

78. Some states presently provide for continuous assessment. See, c.g., ArIz. REv. Stat. ANN. \$ 42-601(b) (1956). Indiana provides for semi-annual assessment of mobile homes. IND. ANn. Stat. § 64-3305 (Supp. 1960).

79. See BartLEy \& BaIR 41-42; see generally Findley, Own Your Own Lat at Trailer Estates, Trail-R-News, March 1960, p. 10.

80. See Crawford v. Wesleyville, 68 Pa. D. \& C. 215, 216 (C.P. 1949); see generally Bartley \& BaIr 99.

81. See, e.g., Barnes v. Gorham, 12 Misc. 2d 285, 287, 175 N.Y.S.2d 376, 378 (Sup. Ct. 1957) ; Crawford v. Wesleyville, 68 Pa. D. \& C. 215, 216 (C.P. 1949) ; Kelly v. City of San Diego, 63 Cal. App. 2d 638, 641 (1944). Rentals presently are unlawful in California. Car. Health \& Safety Code $\$ 18252$.

82. E.g., ARK. Stat. \$ 75-133.3 (1957); Idaho Code ANN. § 49-155 (Supp. 1961); Ind. Ann. Stat. § 42-102 (Supp. 1961); Kan. Gen. Stat. Ann. \$ 8-173 (Supp. 1959).

83. Many states issue permits to move large mobile homes only to licensed transporters. E.g., Ark. Stat. ANN. \$§ 75-822, -823 (Supp. 1960); Cal. Vehicle Code $§ 35790$. 
sanctions are brought to bear on violation of the permit regulations, it is not likely they will prove an effective adjunct to the tax program. The cost of locating a tax delinquent home which had been moved and foreclosing the tax lien might alone be prohibitive. Even greater security could be provided if the tax, though due from the home owner, were made a lien upon the land. ${ }^{84}$ The land owner in turn, if forced to pay the tax to prevent foreclosure, would be given a lien on the home to the extent of the tax paid on its behalf. ${ }^{85}$ Despite this modicum of protection a landowner subject to such a lien for the tax deficiencies of his tenants could be expected to cooperate fully with the authorities by reporting all movements of mobile homes by his tenants. Such a scheme should therefore contribute directly to the enforcement of moving permit requirements and indirectly to the collection of taxes due from mobile home owners.

A somewhat similar result could be achieved if homes located on rented land were assessed directly to the landowner. ${ }^{80}$ This, however, would raise other difficult problems. Extending the benefits of special tax exemptions to particular groups of mobile home users would be more difficult. In the first place, it would be difficult to make sure the occupants received the intended tax benefit in the form of reduced rent. Secondly, land owners might justly complain that homes, present on the day of assessment, may not remain the entire tax year and that others as valuable may not replace them. ${ }^{87}$ On the other hand, the park owner may get a windfall if more valuable units enter after assessment date. ${ }^{88}$ Moreover, the park owner can protect himself by collecting in advance an amount equal to the full year's taxes on the mobile home. Similarly, increased operating costs caused by changes in $\operatorname{tax}$ rates can be shifted to the residents by careful drafting of their leases. Indeed, the park owner may profit from the system if, after collecting. the tax before its due date, he is able to pocket the interest on these funds in the interim together with any discount the municipality offers for early payment of taxes. ${ }^{89}$

Previous attempts to tax mobile homes as realty have been subjected to a variety of legal attacks. The realty tax has been challenged by both

84. Cf. Artz. Rev. Stat. ANn. § 42-203 (1956).

85. In many states park owners have a statutory lien on mobile homes for various charges. E.g., Fla. Stat. ANN. § 85.28 (1943) ; N.M. Stat. ANN. \$§ 61-3-14, -3-16 (1960). Land owners could protect themselves by requiring home owners to make a deposit from which, on departure, unpaid taxes could be deducted.

86. In New York mobile homes may be assessed to the owners of the land on which they are located. N.Y. TAX LAws $\$ 2(6-a)$.

87. Cf. New York Trailer Coach Ass'n v. Steckel, 208 Misc. 308, 312, 144 N.Y.S.2d 82, 86 (1955), rev'd on other groumds, 3 App. Div. 2d 643, 158 N.Y.S.2d 179 (1956).

88. Although there is no indication that current park rentals are graduated according to the value of the home to be placed upon them, such graduation would probably result from assessing the value of the mobile homes to the park owners.

89. See Fla. Stat. ANn. § 193.41 (1958). 
home ${ }^{90}$ and park ${ }^{91}$ owners who claim the homes are personalty. In some cases, support was drawn from the common law of "fixtures," under which the dispositive issue was whether an "intent" to make a permanent attachment could be found. ${ }^{22}$ Since such an intent was hard to establish where mobile homes were concerned, some courts applying the fixture doctrine concluded that they could not be taxed as realty. ${ }^{93}$ This refusal to permit the extension of the realty tax may have been predicated in part on a reluctance to proceed in the absence of legislation specifically authorizing communities to tax mobile homes as realty. ${ }^{94}$ The first pre-statute decisions, now a decade old, subordinated community needs for revenues to a concern for the plight of park owners who would be liable for taxes on homes which might vanish overnight. ${ }^{95}$ Perhaps these cases should have been decided on whether the community had given the landowner sufficient time to shift the tax to the residents, either directly through prepayment for taxes or indirectly through advance rent deposits or increased rents. The owner's legitimate demands would seem to be met if tax rebates were made in situations where the owner had not been afforded a reasonable period in which to protect himself before the tax was levied. Where, however, the park owner received due notice or was eligible for tax refunds, he would seem to be in no different position vis-a-vis the realty tax than any other landlord in the community.

Instead of trying to divine whether state legislation meant the words "personalty" or "realty" to retain their common law definition, the question the courts might better have sought to determine is why the legislature exempted personalty from the category of items to be taxed, and whether the reasons would apply to mobile homes. One reason for exempting tangible personalty, particularly inventories, is that the value of property on hand changes throughout the year making it unfair to pick a specific day for assessment, and too difficult to determine an average value. ${ }^{96}$ This would hardly justify extending the exemption to the mobile home; its value, like that of

90. See, e.g., Hartman v. Fulton County, 24 Pa. D. \& C. 2 d 611 (C.P. 1961) ; Coyle Assessment, 17 Pa. D. \& C. $2 d 149$ (C.P. 1958) ; Fryer Appeal, 81 Pa. D. \& C. 139 (C.P. 1951).

91. See, e.g., Barnes v. Gorham, 12 Misc. 2d 285, 175 N.Y.S.2d 376 (Sup. Ct. 1957); Beagell v. Douglas, 2 Misc. 2d 361, 157 N.Y.S.2d 461 (Sup. Ct. 1955); Streyle v. Board of Property Assessment, $173 \mathrm{~Pa}$. Super. 324 (1953).

92. See generally 5 AMIrRICAN LAw OF Property $\$ 19.3$ (Casner ed. 1952).

93. See, e.g., Barnes v. Gorham, 12 Misc. $2 d$ 285, 175 N.Y.S.2d 376, 387 (Sup. Ct. 1957) ; Streyle v. Board of Property Assessment, 173 Pa. Super. 324, 328-29 (1953); Mason Appeal, 75 Pa. D. \& C. 1, 8-9, 12 (C.P. 1950).

94. See Stewart v. Carrington, 203 Misc. 543, 546, 119 N.Y.S.2d 778, 781 (Sup. Ct. 1953). But cf. Barnes v. Gorham, supra note 93 (statute specifically authorizing assessment of mobile homes as realty found unconstitutional.).

95. See, e.g., Mason Appeal, 75 Pa. D. \& C. 1, 2 (C.P. 1950) ; Fryer Appeal, 81 Pa. D. \& C. 139, 142-43 (C.P. 1951) ; Streyle v. Board of Assessments, 173 Pa. Super. 324,328 (1953).

96. See, e.g., Grove, Financtng Governaent 93 (4th ed. 1955). 
other dwellings, remains relatively constant throughout the year. Another reason given for exemption is that personalty is often difficult to appraise fairly, there being no adequate standards for assessing used home furnishings or wardrobes..$^{97}$ But mobile homes do have readily determined market values. ${ }^{98}$ Another persuasive reason for exempting personalty may have been the ease with which it is concealed $;^{99}$ honest taxpayers are penalized and the dishonest benefitted if services are supported through taxes on property so easily hidden. The visibility of mobile homes, however, is substantially greater than that of securities, cash, clothing and other personalty. Had these courts recognized that mobile homes are, after all, homes, that they serve the same function as other housing, there might have been considerably less reluctance to tax them as other homes are taxed-as realty. Notwithstanding the fact that the exemption of the homes of one class of residents restricts the tax base and arbitrarily shifts their share of the tax burden to other residents, ${ }^{100}$ these cases demonstrate that specific enabling legislation may be necessary if courts are to be persuaded that communities should be allowed to tax mobile homes as realty.

In Pennsylvania and New York, the legislatures did attempt to provide express statutory authority to levy a realty tax on mobile homes against landowners on whose property the home was found on assessment day. ${ }^{101}$ The Pennsylvania statute, however, opens the door to the same factual disputes which plagued the common law by including in its definition of taxable real estate only mobile homes "permanently attached to the land." The only two cases to have construed this limitation indicate the difficulty of predicting the

97. See, e.g., Poole, Public Finance \& Economic Welfare 279 (1956); Grove, supra note 96 , at 69.

93. Market values are presently used in mobile home appraisal. See Mrss. ConE ANv. $\S$ 10007-10 (Supp. 1958); Ky. Rev. Stat. \$ 132.485 (2) (1960).

99. Poole, supra note 97, at 279. Due, Governarent Finance 390-91 (1959).

100. See generally DuE, supra note 99 , at 391 ; Grove, supra note 96 , at 85.

101. N.Y. TAX Laws $\$ 2$ (6-a) provides:

a. In addition to their meaning as provided in subdivision six, the terms "land," "real estate," and "real property," as used in this chapter, include all the forms of housing which are adaptable to motivation by a power connected thereto or which may be propelled by a power within themselves and which are or can be used as a house or living abode or habitation of one or more persons, or for business, commercial or office purposes, either temporarily or permanently, and commonly called and hereafter referred to as "trailers"; except (1) transient trailers which have been located within the boundaries of a tax district for less than sixty days and (2) trailers which are for sale and which are not occupied.

b. Trailers shall be assessed to the owners of the real property on which they are located.

c. For the purposes of this subdivision, the term "tax district" shall include a village.

PA. Stat. Ann. tit. 72, § 5020-201 (Supp. 1960) provides:

The following subjects and property shall ... be ... subject to taxation for all county, city, borough, town, township, school and poor purposes at the annual rate:

a. All real estate, to wit: Houses, house trailers permanently attached to land.... 
classification into which the typical mobile home will fall. In Coyle Assessment, ${ }^{102}$ three homes were assessed to a landowner who owned but one of them. The homes rested on cement blocks, were connected to utilities, and had been in place over two years. The court disregarded "self serving statements by the parties" who denied any intent to make a permanent attachment, and found sufficient actual attachment to justify considering the homes as realty. ${ }^{103}$ In Hartman v. Fulton County, ${ }^{104}$ however, a contrary result was reached despite the fact the home there involved had also been placed on cement blocks and connected to utilities. Thus, tax assessors, park owners, and mobile home occupants trying to forecast the decision in the next "attachment" case have a predictability factor the same as a gambler who bets the tossed coin will land on its head. Whatever its predictive deficiencies, however, the Pennsylvania statute has been upheld against fourteenth amendment challenges. ${ }^{105}$

New York's enabling statute, on the other hand, which has no attachment limitation, has been held unconstitutional in two of the four lower courts in which it has been challenged. ${ }^{106}$ The irrepressible vitality of the common law is evidenced by the fact that both of these courts admitted that no constitutional objection would have been sustained had the assessed mobile homes been attached. ${ }^{107}$ Apparently these two New York courts were troubled by the possibility of the landowner being held liable for tax on homes which did not remain on his property. ${ }^{108}$ But the sole authority cited by either New York court to support the contention that property may not constitutionally be assessed to a person other than its owner was Hoeper v. Tax Commission. ${ }^{100}$ That 1931 United States Supreme Court opinion, occasioning vigorous dissent when written ${ }^{110}$ and distegarded or distinguished ever since, ${ }^{111}$ held invalid a Wisconsin statute which taxed a husband for his wife's income. The

102. 17 Pa. D. \& C. $2 d 149$ (C.P. 1958).

103. Id. at 152 .

104. 24 Pa. D. \& C. $2 d 611$ (C.P. 1961 ).

105. Coyle Assessment, 17 Pa. D. \& C. 2d 149, 153 (C.P. 1958).

106. Compare Beagell v. Douglas, 2 Misc. 2d 361, 157 N.Y.S.2d 461 (Sup. Ct. 1955) and Feld v. Hanna, 4 Misc. 2d 3, 158 N.Y.S.2d 94 (Sup. Ct. 1956) with Barnes v. Gorham, 12 Misc. 2d 285, 175 N.Y.S.2d 376 (Sup. Ct. 1957) and New York Trailer Coach Ass'n v. Steckel, 208 Misc. 308, 144 N.Y.S.2d 82 (Sup. Ct. 1955), rev'd on other grounds, 3 App. Div. 2d 643, 158 N.Y.S.2d 179 (1956).

107. Barnes v. Gorham, supra note 106, at 296, 175 N.Y.S.2d at 386-87; New York Trailer Coach Ass'n v. Steckel, stupra note 106, at 311, 313, 144 N.Y.S.2d at 86, 88.

108. Barnes v. Gorham supra note 106, at 294-95, 175 N.Y.S.2d at 385; New York Trailer Coach Ass'n. v. Steckel, supra note 106, at 312, 144 N.Y.S.2d at 86.

109. 284 U.S. 206 (1931).

110. Dissent by Mr. Justice Holmes, joined by Mr. Justice Brandeis and Mr. Justice Stone. 284 U.S. at 218.

111. Fernandez v. Wiener, 326 U.S. 340, 365 (1945) (concurring opinion); Whitney v. State Tax Comm'n, 309 U.S. 530, 541 (1940); Reinecke v. Smith, 289 U.S. 172, 178 (1933); Albanese D'Imperio v. Secretary of Treasury, 223 F.2d 413, 415 (1st Cir. 1955) ; Ballester v. Descartes, 181 F.2d 823, 828-29 (1st Cir. 1950). 
husband in that case had no claim or control over his wife's income, nor any means short of divorce to prevent the tax liability from accruing against him. These factors are not present in the case of a park owner assessed for mobile homes located on his property. In commercial contexts property taxes imposed upon non-owners have been upheld if the taxpayer was in a position to receive financial benefit from the property for which he was taxed.112 The test of due process enunciated by the Supreme Court in Ott v. Mississippi Valley Barge Line Co. ${ }^{113}$ "is whether the tax in practical operation has relation to opportunities, benefits, or protection conferred or afforded by the taxing State."114 That the park owner benefits from general public services even the two protesting New York courts conceded.115 One of the courts even suggested that the park owners' land assessment should be increased to make them "responsible for the proportionate cost of government which should be borne by the trailer residents upon such land."116 This is precisely what the realty tax, assessing homes to the landowner, seeks to accomplish.

Thus it would seem that there is no constitutional impediment to extending realty taxes to mobile homes, at least where they can be said to be "permanently" attached to the land. What constitutional problems have arisen were occasioned by attempts to tax the owners of the land on which the mobile homes rested rather than the owners of the homes; and even this hurdle seems surmountable in view of the modern commercial setting if it should be deemed more efficient to levy the tax, in first instance, on the landlord. And the administrative difficulties which would attend such an extension of realty taxes have been shown to be of a relatively low order. There seems therefore to be no justification for the maintenance of the present systems with their inherently unequal treatment of one group of home owners. If progress is to be made in this direction, however, it will have to be initiated in many jurisdictions on the state rather than the local level. Even if specific enabling legislation should ultimately prove unnecessary, many communities will be unable to tax mobile homes because of existing legislation permitting the home owners to pay certain fees in lieu of all other taxation of their mobile homes. With mobile homes being produced at an ever-increasing rate, it is time the community turned its attention to equalizing its tax treatment of home owners generally.

112. See Illinois Cent. R.R. v. Kentucky, 218 U.S. 551 (1910); Thompson v. Kentucky, 209 U.S. 340 (1908) ; Carstairs v. Cochran, 193 U.S. 10 (1904).

113. 336 U.S. 169 (1949).

114. Id. at 174.

115. . Barnes v. Gorham, 12 Misc. 2d 285, 293, 175 N.Y.S.2d, 376, 384 (Sup. Ct. 1957); New York Trailer Coach Ass'n v. Steckel, 208 Misc. 308, 311, 144 N.Y.S.2d 82, 85 (Sup. Ct. 1955).

116. Barnes v. Gorham, supra note 115 , at 293,175 N.Y.S.2d at 384 . 